\title{
Forest Tenures - Requirements, Rights and Responsibilities: An Economic Perspective
}

\author{
by
}

Martin K. Luckert and David Haley ${ }^{1}$

\section{Abstract}

The nature of forest tenure arrangements is analysed in terms of requirements, rights and responsibilities. The standards of private management of Crown lands frequently fall below public expectations because: (a) the benefits that rights confer on tenure holders are entirely, or partially, appropriated for the Crown through the imposition of stringent legal requirements; and/or (b) the rights, themselves, are of ambiguous legal status and non-compensable, thus introducing considerable uncertainty into forest tenure arrangements. Without security, tenure holders have less incentive to voluntarily manage Crown forests.

Who should manage Crown forests? - is a judgmental question that depends on society's notions of what is morally correct or equitable. Who will manage Crown forests? - is an economic and legal question, the answer to which depends on the existence of legal rights and on the legal requirements imposed by forest tenure agreements.

\section{Résumé}

La nature des dispositions entourant les concessions forestières est analysée en terme de besoins, de droits et de responsabilités. Les critères d'aménagement forestier des terres publiques sont fréquemment sous les attentes du public parce que: (a) les bénéfices conférés par les droits des détenteurs de concessions sont entièrement, ou partiellement, appropriés pour les terres publiques par suite d'exigences légales rigoureuses; ou encore, (b) les droits, par eux-mêmes ont indemnisables un statut légal ambigu et non-indemnisables, ce qui ouvre la porte à beaucoup d'incertitude parmi les dispositions des concessions forestières. Sans cette sécurité les déten. teurs de concession sont moins incités à aménager volontairement les terres de la Couronne.

Qui devrait aménager les terres publiques? demeure une question de discernement qui dépend des notions de la société permettant de définir ce qui est moralement correct ou équitable. Qui effectuera l'aménagement des forêts publiques? devient une question économique et légale, la réponse étant basée sur l'existence de droits légaux et de besoins légaux imposés par les accords définissant les concessions forestières.

\section{Introduction}

In many countries with forest resources there is considerable public involvement in their ownership and management. Governments in Canada, both provincial and federal, have retained title to a remarkably high proportion of forest land. For the country as a whole, only $6 \%$ of the 342 million hectares of forest land is in private ownership (Bonnor 1981). Only in New Brunswick, Nova Scotia and Prince Edward Island do private ownerships comprise a substantial proportion of the provinces' forest land.

While the vast majority of forest land in most regions of Canada is publicly owned, timber harvesting and forest products manufacturing enterprises are almost entirely in private hands. As a result, forest policy makers, since the earliest days of land settlement, have been concerned with the task of transferring harvesting rights on public forest land to the private sector. Consequently, tenure arrangements have emerged throughout Canada as major instruments of public forest policy which have evolved in response to varied social values and needs.

The development of forest tenures is an ongoing dynamic process as provincial governments react to changing social objectives and priorities. During the last decade or so, several

\footnotetext{
'Respectively, Post-Doctoral Research Fellow and Associate Professor, Department of Forest Resources Management, Faculty of Forestry, University of British Columbia, Vancouver, B.C. V6T 1W5.
}

Canadian provinces have undertaken comprehensive reviews of their forest tenure systems which have resulted in new policy directions (Anonymous 1981, 1983, 1985; Fullerton 1984; Pearse 1976; Watson 1984).

In view of the importance of forest property right issues in Canada, there is a need to develop a better understanding of how alternative tenure arrangements may affect the behaviour of private firms in the forest sector. Effective policies can only be efficiently designed if their impacts are understood and can be predicted with some degree of confidence.

In this paper, three terms commonly used in formulating and analyzing forest tenures - requirements, rights and responsibilities - will be discussed. Their interpretation holds the key to a better understanding of several forest policy issues, particularly the all important questions of who should and who will manage public forest resources.

\section{Requirements}

Any tenure agreement imposes some legal obligations on the involved parties. A private sector forest company in Canada entering into a tenure contract with the Crown to harvest timber agrees to meet certain requirements or conditions. These requirements vary from region to region, may vary from tenure type to tenure type and change over time. They are designed to achieve varied social objectives 
including the generation of revenue, conservation of the resource, the survival of manufacturing facilities and communities, and the protection of non-timber values. Failure on the part of a tenure holder to comply with these requirements usually results in penalties.

When requirements exist, they impose costs on tenure holders whose net benefits, resulting from profit maximizing behaviour, are reduced. Requirements such as mandatory utilization standards, for example, may force firms to harvest logs that they would otherwise regard as being economically sub-marginal, thus reducing their net revenues (Nautiyal and Love 1971; Uhler and Morrison 1986). Likewise, controls on the volume of timber that can be harvested annually - a requirement in most forest tenure contracts in Canada - may severely constrain the profit objectives of firms. Requirements invariably reduce the benefits that private firms can expect from holding a forest tenure.

\section{Rights}

Benefits accrue to forest tenure holders from the rights that they hold. Rights allow tenure holders to capture benefits in excess of the costs they bear in meeting their contractual requirements. For example, a tenure holder can be said to have a right to harvest timber if the costs of meeting such requirements as utilization standards and environmental protection standards are less than the value of the timber harvested, net of stumpage, royalties and other mandatory charges. If the costs of meeting contractual requirements exceed the benefits from harvesting timber, then the tenure holder will not wish to harvest. In such cases, the tenure holder has no harvesting rights - they have, in effect, been expropriated. In British Columbia, recent changes in the method of charging for Crown timber have raised stumpage fees in some parts of the province so high that, it is claimed, private sector returns to timber harvesting have been reduced to zero - that is timber harvesting rights no longer exist. One major forest products company is challenging the provincial government in the courts on the issue.

A right, according to Webster (1976), is a valuable entity over which an individual, or firm, has a just or legal claim. If a right is legally founded, there are institutionalized executive and/or judicial systems that establish and, if necessary, uphold the property holder's right within society. Such rights, if removed or reduced, are generally compensable. Compensation may be established by statute or may be a matter of civil action.

On the other hand, if a right is justly founded it is neither established through nor directly protected by the legal system. In some cases, such rights are established through the legislative process but, in others, may arise as a matter of custom or usage and reflect the perceptions of the parties concerned as to what is fair and equitable. As far as compensation is concerned, justly founded rights fall into a grey area. They may become the subject of legal interpretation causing their holders to face a higher degree of uncertainty in regard to compensation than in the case of legally founded rights.

Forest tenure arrangements in Canada are generally a combination of legal and just rights but lean heavily towards the latter. Some rights, if revoked; are clearly compensable under provincial statutes ${ }^{2}$, however, many are not.

\footnotetext{
${ }^{2}$ For example, in British Columbia Tree Farm License holders, under sections 53(2)(a)(i) and (ii) of the Forest Act are entitled to compensation for deletions from the area of their licenses for non-timber uses in respect of the amount that the deletion reduces the allowable cut of the license by more than 5 percent.
}

The distinction between legal rights and just rights is important when considering the questions of who should and who will manage the forest. Who should manage Crown forests? - is a judgmental question, the answer to which depends upon society's notion of what is morally correct or equitable. Through the political system, such value judgments profoundly influence the development of tenure arrangements. Thus, if society feels that firms with rights to Crown timber should replace the forest following harvest, then it is likely that tenure contracts will be designed that attempt to accommodate this concern.

However, the moral question of who should manage the forest is very different from the economic and legal question of who will manage the forest. Tenure holders will manage the forest if they have legally established rights to do so. That is, if the benefits they derive from management exceed the contractual and other costs of exercising their management rights, and if these rights are legally protected. In the case of reforestation and stand tending, secure management rights must not only exist but must be assured for at least one rotation and, ideally, should be transferable.

Management rights founded upon solciety's perceptions of "fair play" or justice do not offer the security that legally protected rights do. Without security, tenure holders will have less incentive to manage Crown forests.

\section{Responsibilities}

Responsibility can be defined as legal or moral accountability for conduct and obligations (Webster, 1976).

Legal responsibility to meet contractual obligations is synonymous with requirements. That is, tenure holders can be held legally accountable for carrying out the management operations required under their contracts.

Moral responsibility differs markedly from legal responsibility. Individual citizens or groups might, and frequently do, contend that private firms have a moral repsonsibility to society, both present and future, to re-establish timber crops following harvesting and manage the public forest land under their temporary control in a socially desirable manner. However, forest tenure holders cannot be expected to make decisions affecting their own welfare according to what they perceive as being appropriate for society. It is no more reasonable to expect private firms to be motivated by the public interest, as far as land management is concerned, than it is to expect them, or any other individual or group for that matter, to voluntarily pay income tax or any other levy to government. Moral responsibility relates to the question of who should manage the forest. Who will manage the forest is a question of legal responsibilities.

\section{Who Should and Who Will Manage the Forest?}

The concepts of requirements, rights and responsibilities (the three Rs of forest tenures) and how they affect forest management are summarized in Figure 1.

In designing forest tenures, governments are faced with establishing a delicate balance between requirements, rights and responsibilities. Who will manage public forests depends on the legal requirements contained in forest tenure arrangements and the commensurate legal responsibilities imposed on tenure holders. It also depends on the existence of legal rights which, by their very nature, provide tenure holders with incentives to voluntarily manage forests by allowing them to capture some of the benefits of their activities. 
If requirements that governments place on tenure holders are too stringent then the benefits that rights confer on tenure holders may be entirely appropriated by the public sector and incentives for voluntary management of the resource will no longer exist. On the other hand, certain social objectives, for example the maintenance of water standards for downstream users or the creation of visually acceptable landscapes, can often only be achieved through legal requirements and regulations since it is difficult, or impossible, to establish rights that adequately ensure their provision.

The legal rights created by tenure agreements, together with the legal requirements and responsibilities imposed on tenure holders, jointly determine the extent to which social objectives for public forest land can be met through private sector activities. However, the manner in which public forests are managed by the private sector may not accomplish the objectives that governments pursue on behalf of society.

Members of society may, and frequently do, feel that the private sector's management responsibilities lie far beyond their actual achievements. An important reason for this gap between society's expectations of who should manage public forests and the reality of who will manage public forests, is the fact that many of the so-called "rights" granted by tenure agreements, while they reflect society's aspirations as far

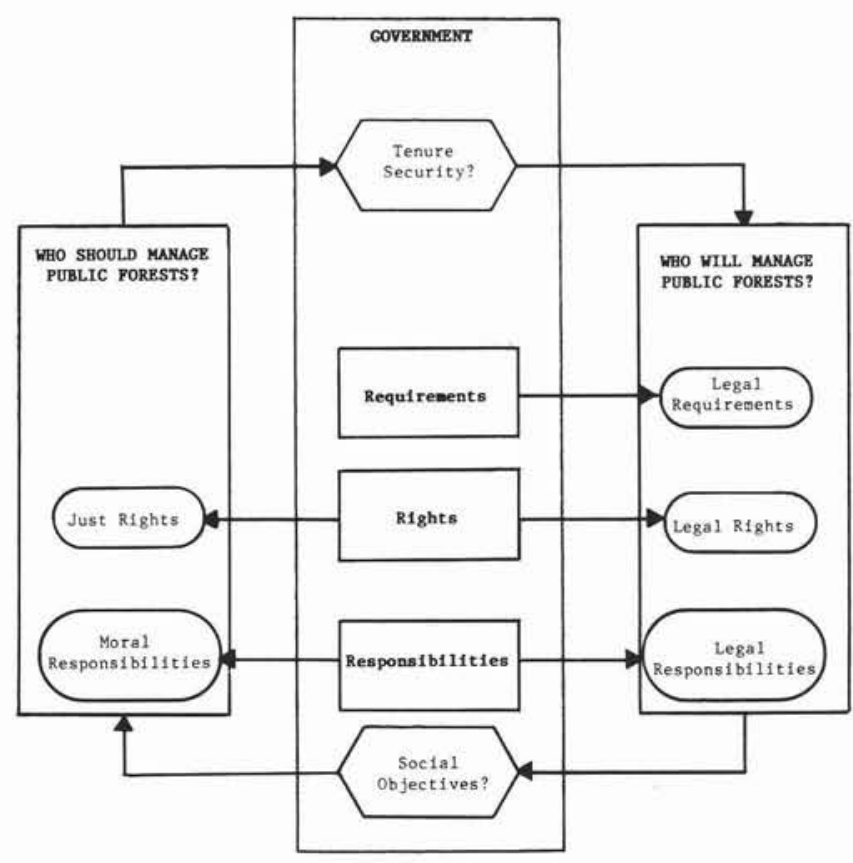

Figure 1. Tenure requirements, rights and responsibilities and their impact on forest management.

as a desired level of forest management is concerned, are of ambiguous legal status and are non-compensable. Governments frequently try to close the gap between societal expectations and reality by enacting more comprehensive and/or stringent legal management requirements. These new requirements impose additional costs on tenure holders and further erode their rights. "Just rights", as they were referred to earlier in this paper, by their vary nature, introduce considerable uncertainty into forest tenure arrangements. Forest tenure holders, frequently as the result of experience, feel insecure in their agreements with the Crown. This insecurity reduces incentives for forest management which, in turn, influences who will manage the forests.

\section{Conclusion}

Throughout Canada, forest tenure agreements designed to involve private capital and entrepreneurship in the harvesting of public timber and the management of public forest lands have become pervasive and extremely important instruments of public policy. Frequently, the standard of management, or resource stewardship, achieved under such agreements falls far short of public expectations and social goals are not achieved. The task of designing contracts between the Crown and the private sector, that best further social objectives, is clearly not an easy one. Nevertheless, it is of the utmost importance.

In this paper, the nature of forest tenure arrangements has been analyzed in terms of requirements, rights and responsibilities. The precise meanings of these terms have been discussed and the ways in which they interacted to influence the behaviour of forest tenure holders have been explained. Interpreting these terms provides insights into several policy issues. Particularly, the moral question of who should manage public forests given societal values, is distinguished from the legal and economic question of who will manage the forests given the incentives created by tenures. Furthermore, these two questions are shown to be closely interrelated. Given the importance of understanding tenures to the development of efficient public forest policies, far more research - economic, legal and behaviorial - is required in this important field.

\section{References}

Anonymous. 1981. Task force on forest management: Final report of the task force on forest management to the Minister of Natural Resources. New Brunswick. Fredericton. 65pp.

Anonymous. 1983. A submission to the Nova Scotia Royal Commission on Forestry. Nova Scotia Dept. Lands and For., Halifax. $106 \mathrm{pp}$.

Anonymous. 1985. Building a forest for tomorrow: The forest policy. Government of Quebec. 98pp.

Bonnor, G.M. 1981. Canada's forest inventory, 1981. Environ. Can., Can. For. Serv., For. Stat. Br. Ottawa.

Fullerton, W.K. 1984. The evolution of Crown land forest policy in Ontario. For. Chron. 60: 63-66.

Nautiyal, J.C. and D.V. Love. 1971. Some economic implications of methods of charging stumpage. For. Chron. 47: 25-28.

Pearse, P.H. 1976. Timber rights and forest policy in British Columbia. Re. Royal Comm. For. Resour. Victoria, B.C. Vols. 1 and 2.

Uhler, R.S. and P.D. Morrison. 1986. Utilization standards and economic efficiency in the British Columbia forest industry. Univ. British Columbia, Forest Economics and Policy Analysis Project. Info. Rep. 86-1. 17pp.

Webster. 1976. Webster's Seventh New Collegiate Dictionary. G. and C. Meriam Springfield.

Watson, R.S. 1984. New Brunswick's forest policy - facing the future. For. Chron. 60: 71-74.

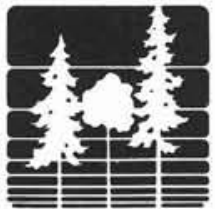

